\title{
INVESTMENT ACTIVITY OF THE TERRITORIAL SELF-GOVERNMENT IN POLAND
}

\author{
AGNIESZKA JACHOWICZ, ${ }^{1}$ MAGDALENA KOGUT-JAWORSKA, ${ }^{2}$ \\ JOLANTA ZAWORA ${ }^{3}$ \\ ${ }^{1}$ University of Dabrowa Gornicza, POLAND \\ e-mail: jahowicza@interia.pl \\ ${ }^{2}$ University of Szczecin, POLAND \\ e-mail: magdalena.kogut@wzieu.pl \\ ${ }^{3}$ University of Rzeszów, POLAND \\ e-mail: jolazawora@gmail.com
}

RECEIVED
ACCEPTED
JEL
CLASSIFICATION

KEYWORDS

ABSTRACT
12 May 2018

10 September 2018

F42, F63, H41, H87

public finance, self-government unit, public-private partnerships

The character of the territorial self-government units activity in Poland and realization of their constitutional goals (own or delegated) is the driver which forces them to undertake investment activities and to make particular expenditures (financial or material). The self - governmental activity and expenditure on investment should, by definition, be aimed at development of the communal infrastructure which will ensure good standard of living for the local population. Equally, the development will contribute into achieving additional economic, social and environmental goals.

The issues related to the financial aspect of the self-governmental investment activity in Poland are the subject of this paper. In particular, the major objective of the author is to analyse the existing financial conditions for investment made by the territorial self-government in Poland and to assess attractiveness of investment financing through intersectional co-operation within public-private partnership. The realization of the objective of the paper has been based on the methods of comparative or descriptive analyses and on the method of descriptive statistics.

\section{Importance and character of investment in terpitorial sell-government units}

The topic of realization and financing of the self-governmental investment in Poland has been a frequent object of research (Jastrzębska, 2012; Patrzałek, 2010; Burzyńska, 2012; Hajdys, 2013; Zioło, 2012; Swianiewicz, 2011; Brzozowska, Gorzałczyńska-Koczkodaj, Kogut-Jaworska, Zioło, 2013; Maśloch, Sierak, 2013). The dominating view says that the level of investment expenditure mirrors in the best way the investment activity of self-governments. 
Other measures of the activity are also stressed, especially those referring to the basic budget characteristics, such as: own income, operational surplus, expenditure on own property (Zawora, 2014). The effect of limited budgets and, at the same time, growing investment needs, leads to intensified search of new forms and methods aimed at realization of investment ventures planned by the territorial self-government units, including co-operation with the private sector within public-private partnership, also called the PPP (Hajdys 2013; Zioło 2013; Jakubowicz, 2013). The summary of the empiric research confirms firmly the importance of investment expenditure in self-governmental finances and their impact on social and economic development. Self-government investment influences positively living conditions and standards of the local community, as well as the environment created for business activity. However, the analysis of the literature leads to the conclusion that the commercial investment differs considerably from the self-governmental type of investment. The latter has a non-profit character and, by definition, the entities do not generate income. Financial means are exchanged for other assets as the effect of realization of investment implemented by the self-governments. It needs to be added that the self-government investment has a continuous character and the connected outlays burden regularly the budgets of communes counties or regions.

Well as further development of the territorial self-government units require constant investment expenditure. The level of the expenditure is conditioned by numerous internal and external factors. The external ones are connected with the rules of financing aimed at achieving public goals, within the existing legal framework and with reference to the overall economic, social and political situation in the country and in the world. The internal factors are connected with the situation inside the self-government, in particular, with the financial, economic and political aspects.

When analysing investment expenditure of self-governments, the objectives set by the laws and regulations need to be taken particularly into consideration. Social objectives do seriously limit possibilities of investment expenditure. On the other hand, investment opportunities are undoubtedly broadened and supported by the EU funding and other external sources for financing development activities (e.g. credit, loans, issuering of bonds). It must be indicated that the EU Funds has been considerably intensifying investment activity of self-government units in the last years, despite existing difficulties - namely the necessity to bring in own financial input.

It must be also remembered that, the territorial self-government investment expenditure is also conditioned by the amount and pace of growing of the souvereign debt. As a consequence, exceeding the allowed amount enforces some limitations for application of external sources of investment funding. Equally, it impels to search alternative methods in order to realise the ventures. Public-private partnership seems to be an innovative and useful way for implementation of investment ventures with the application of the EU funds (or without doing so), when the investment budget limited.

\section{Identification of the determinants conditioning realization of investment activity performed by the territorial self-government units}

Investment activity of territorial self-government units is influenced by economic conditions which are determined by non-financial factors, those legal and organizational ones in the first place. ${ }^{1}$ However, one of the decisive criteria for starting investment is finding and securing ways of its financing (Sierak, Górniak, 2011).

\footnotetext{
${ }^{1}$ More about the structure of communal income and the possibilities of its development: Sadowska (2011), pp. 77-90.
} 
The aim of this part of the paper is to analyse financial conditions for investment activity of the territorial selfgovernment units, as well as the scope and main directions of investment by self-governments. The time frame of the analysis covers the 2009-2016 period. The empiric material comes from the Bank of Local Data of the Main Statistical Office of Poland, the Ministry of Finance and also from the National Council of Regional Accounting Chambers (KRR).

The assessment of the financing aimed at investment activities of the territorial self-government units has been based on the following indicators:

- own income in relation to total income (W1),

- operational surplus in relation to total income (W2),

- investment expenditures in relation to total expenditures (W3),

- total of operational surplus and property income in relation to property expenditures (W4).

Table 1. Indicators of assessment of opportunities for investment financing by territorial self-government units 2009-2016 (\%)

\begin{tabular}{|c|c|c|c|c|c|c|c|c|}
\hline Indicators & 2009 & 2010 & 2011 & 2012 & 2013 & 2014 & 2015 & 2016 \\
\hline \multicolumn{9}{|c|}{ Local communities } \\
\hline W1 & 46.3 & 44.6 & 45.5 & 46.6 & 48.2 & 49.3 & 49.7 & 44.3 \\
\hline W2 & 9.5 & 6.5 & 7.2 & 8.0 & 9.2 & 8.2 & 8.8 & 6.4 \\
\hline W3 & 22.5 & 24.7 & 22.5 & 17.7 & 16.2 & 17.8 & 16.5 & 10.8 \\
\hline W4 & 68.3 & 62.8 & 78.9 & 99.4 & 104.6 & 94.7 & 113.7 & 133.4 \\
\hline \multicolumn{9}{|c|}{ District towns } \\
\hline W1 & 66.1 & 63.6 & 63.2 & 61.1 & 62.4 & 62.8 & 63.5 & 61.6 \\
\hline W2 & 6.4 & 4.7 & 5.4 & 4.8 & 6.0 & 7.0 & 7.8 & 8.2 \\
\hline W3 & 21.5 & 21.5 & 20.1 & 19.0 & 17.6 & 19.6 & 17.5 & 10.7 \\
\hline W4 & 58.9 & 63.2 & 68.1 & 84.9 & 97.5 & 97.2 & 101.4 & 137.4 \\
\hline \multicolumn{9}{|c|}{ Counties } \\
\hline W1 & 27.4 & 27.4 & 27.0 & 28.2 & 28.9 & 30.2 & 32.3 & 33.9 \\
\hline W2 & 4.5 & 3.6 & 5.5 & 4.9 & 5.4 & 6.1 & 6.6 & 8.3 \\
\hline W3 & 19.2 & 21.7 & 18.6 & 12.3 & 12.3 & 14.5 & 14.4 & 12.7 \\
\hline W4 & 70.3 & 76.9 & 95.4 & 127.5 & 132.6 & 116.2 & 129.0 & 149.6 \\
\hline \multicolumn{9}{|c|}{ Regions (Voivodships) } \\
\hline W1 & 27.1 & 34.1 & 37.9 & 36.1 & 34.5 & 33.3 & 37.5 & 46.1 \\
\hline W2 & 10.1 & 10.3 & 10.0 & 10.7 & 10.1 & 10.2 & 10.9 & 14.1 \\
\hline W3 & 47.3 & 37.5 & 39.4 & 35.9 & 38.4 & 42.3 & 43.1 & 24.4 \\
\hline W4 & 92.8 & 83.0 & 83.0 & 90.7 & 97.5 & 97.8 & 102.1 & 137.3 \\
\hline
\end{tabular}

Source: own material based on data from the Main Statistical Office and from the Ministry of Finance (Wskaźniki..., 2017).

Estimate of operational result is useful for analysis of financing capacity of the territorial self-government units. The value of the operational surplus indicator (W2 in Table 1) shows that regional self-governments had relatively more financial means on investment implementation than the other units. On the other hand, counties featured the lowest capability for financing of investment. It must be stressed that the indicator increased in the years 20152016, which is noticeable for all types of the self-government. The cause of the increase is the new mechanism for indebtedness limitation introduced in 2014, according to which the level of the operational surplus achieved decides about possibilities of indebtedness of the self-government unit (Ustawa o finansach..., 2009, article 243). 
The Analysis of self-financing levels shows a broader assessment of investment capabilities of self-governments. The indicator of self-financing (W4) demonstrates to which extent the self-government finances investment by its own means. The level of self-financing was fluctuating considerably in the period researched. However, in majority of the self-government units, it was staying below $100 \%$. The lowest level of the indicator was observed in the years 2009-2011, when investment expenditures of self-governments were the highest, which means that the self-government units reached more often for repayable sources of financing, due to their lower financial capabilities. In the period analysed, the most indebted group among self-government units were district towns (Raport..., 2017).

The value of the W1 indicator - participation of own income in total income - shows that district towns featured the highest level of financial self-dependence (the average value of the indicator was $63 \%$, on the other hand, the lowest level of the self-dependence was a feature of the counties $(29 \%)$. Moreover, the counties showed the lowest level of the investment expenditure indicator in relation to the total expenditure (W3), which on average, amounted to $15.7 \%$. The regions (voivodships) spent most means on investment in relation to total expenditure, on average $38.5 \%$ in the period researched. In the years 2009-2011, the investment expenditures were the highest, which was connected with European Union funds application, as well as with an increase in the self-government indebtedness. In the following years, the share of the investment expenditures was decreasing, the most visibly in 2016. The considerable drop of the indicator was influenced by a sharp increase of the current expenditures (by $22.1 \%$ in comparison with the previous year), mainly because of the realization of a new social scheme ("Family $500+$ programme) resulting from the Parliamentary Act on Family Support aimed at helping parents who bring up children. Besides, the decrease in investment was the effect of the interim period in the EU funds allocation, which concerned both, the old and the new financial perspectives.

Table 2. Investment expenditures of the territorial self-government 2009-2016

\begin{tabular}{lrrrrrrrrr}
\hline \multicolumn{1}{c}{ Specification } & 2009 & 2010 & 2011 & 2012 & 2013 & 2014 & 2015 & 2016 \\
\hline & & \multicolumn{7}{c}{ bln PLN } \\
\hline Territorial self-government units in total, including: & 41.6 & 43.3 & 41.2 & 34.4 & 33.5 & 39.9 & 37.5 & 24.6 \\
$\quad$ communes & 15.8 & 19.7 & 17.9 & 13.9 & 12.8 & 15.1 & 14.2 & 10.6 \\
$\quad$ counties & 4.1 & 5.2 & 4.5 & 2.8 & 2.8 & 3.4 & 3.4 & 3.0 & 7.4 \\
$\quad$ district towns & 12.1 & 12.7 & 12.4 & 12.1 & 11.4 & 13.6 & 12.2 & 7.7 \\
$\quad$ regions & 9.7 & 5.7 & 6.4 & 5.7 & 6.4 & 7.7 & 7.7 & 3.3 \\
\hline & & & & & $\%$ & & & & \\
\hline Territorial self-government units in total, including & 100.0 & 100.0 & 100.0 & 100.0 & 100.0 & 100.0 & 100.0 & 100.0 \\
$\quad$ communes & 37.9 & 45.4 & 43.4 & 40.4 & 38.4 & 37.8 & 37.9 & 43.1 \\
$\quad$ counties & 9.9 & 12.0 & 10.9 & 8.1 & 8.4 & 8.5 & 9.1 & 12.2 \\
$\quad$ district towns & 29.1 & 29.3 & 30.1 & 35.2 & 34.2 & 34.1 & 32.5 & 31.3 \\
$\quad$ regions & 23.3 & 13.2 & 15.5 & 16.6 & 19.0 & 19.3 & 20.5 & 13.4 \\
\hline
\end{tabular}

Source: own compilation based on the KRRIO data (Sprawozdanie..., 2017).

The major part of the self-governmental investment is realized by the communes and district towns their total participation in the period researched exceeded $70 \%$ of all territorial self-government investment. The self-government units spent almost 300 bln PLN on realization of investment ventures in the period 2009-2016, 
the most of that was spent by communes (120 bln PLN) and district towns (94 bln PLN). County budgets were least burdened by investment activity - 29 bln PLN (Table 2).

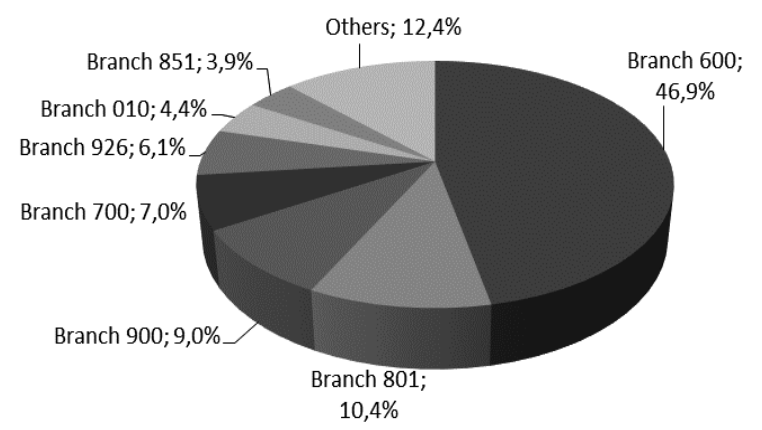

Branch 600 - Transport and Communication, branch 801 - Education, branch 900 Utilities and Environment Protection, branch 700 Housing, branch 926 Physical Education, branch 010 Agriculture and Hunting, branch 851 - Healthcare.

Figure 1. Structure of investment expenditure by the territorial self-government units according to particular branches of economy or administration in 2016 (\%)

Source: own compilation based on the KRRIO data (Sprawozdanie..., 2017).

The main investment direction chosen by the self-government units have not been changing in the last years. The dominating scope of the territorial self-government investment activity has been transport and communication. In 2016, the expenditure on road construction end modernization accounted for almost a half of the total self-governmental expenditure (46.9\%). The less supported spheres of activity included education (10.4\%) as well as utilities and environment protection (9.0\%). The above mentioned scopes of investment activity performed by self- governments were determined by the social and economic needs as well as by objectives set for the local self-government entities.

\section{Public and private sector partnerships in financing self-yovernment investments}

Public private partnerships are a tool for completing public projects and combine private innovation and public duty. This part of the article deals with the situation of Polish PPP regarding public projects, especially in self-governing units. The study researches of Polish public self-governing units, which are now engaged in PPP agreements.

Public Private Partnerships create the possibility for the public sector to complete major projects, in collaboration with partners in the private sector. On the public side, the incumbent government has the obligation to satisfy ever-growing social needs, and fulfilling these expectations presents difficulties, especially with a growing deficit which limits the possibilities of investment. The private sector is interested in this form of partnership, as it presents it with an opportunity to win public sector contracts that will increase long-term profits (Jachowicz, 2016). The aim of public private partnerships could be described as the optimization of resources for completing largescale projects, which lie within the competence of the public sector. 
In reality, the cooperation of two economic entities means a division of duties and risks adequate to their capacity. It was pointed out by the European Committee, which claims that "(...) partners have their shared rights and duties, and when the terms are not followed, this partnership does not work. The partnership requires the will to cooperate from all the involved parties (...)" (EU, p. 12).

The force behind the PPP project is the private partner with its management skills, access to technology and capital capacity. The public partner is responsible for the project through all its stages and, contrary to traditional methods, is not a service provider any more, but a project manager throughout the agreement. It carries the responsibility for the development of cooperation between the partners, taking into account the aims, standards and legislation involved (Korbus, Strawiński, 2006).

According to W. Orłowski's estimate, the Polish public service sector needs an annual investment growth from 4.4\% GDP to 5\% GDP between 2020-2022 (based on 2010 data), to reach the current Western European level. The difference between the available and the estimated resources shows the investments needed. The gap set between 2011-2022 amounts from about 111 billions PLN to almost 2000 billion PLN (at fixed prices for 2009). Annualized investment value is placed between 4-7 billion PLN, which is insufficient to decrease the gap between Poland and developed EU countries. The question is - how to finance those ventures? Public private partnerships create a chance to take the strain off the public sector budget while completing planned and necessary investments (Jachowicz, 2015).

According to the Institute of PPP's (2017) and the author's research (2017), in the period from the beginning of 2009 till the 30 June of 2017, the number of PPP agreements, in Poland, rose to 490 (Figure 2).

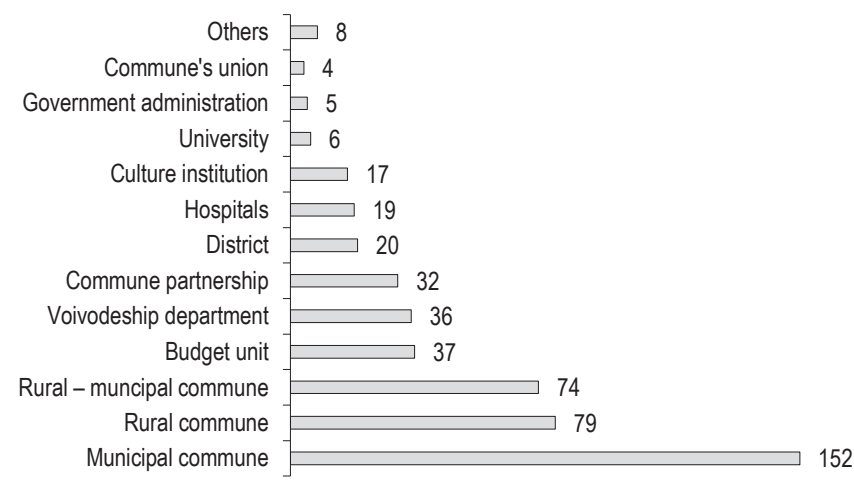

Figure 2. Number of initiated PPP's agreements 2009-2017

Source: own research and PPP' Institute.

As we can see from figure 2 the vital role was played by the self-governing units, especially communes, as they had debt limits and had to calculate accordingly the individual gearing ratio, which came into force in 2014. The next very important factor was novelisation i.e. the Polish law about PPP in 2008 and the concession laws in 2008 and 2016. The results show that the scale of the Polish PPP market amounted to 5,000 million PLN. That amount was invested in projects of different value, which are illustrated in Figure 3. 


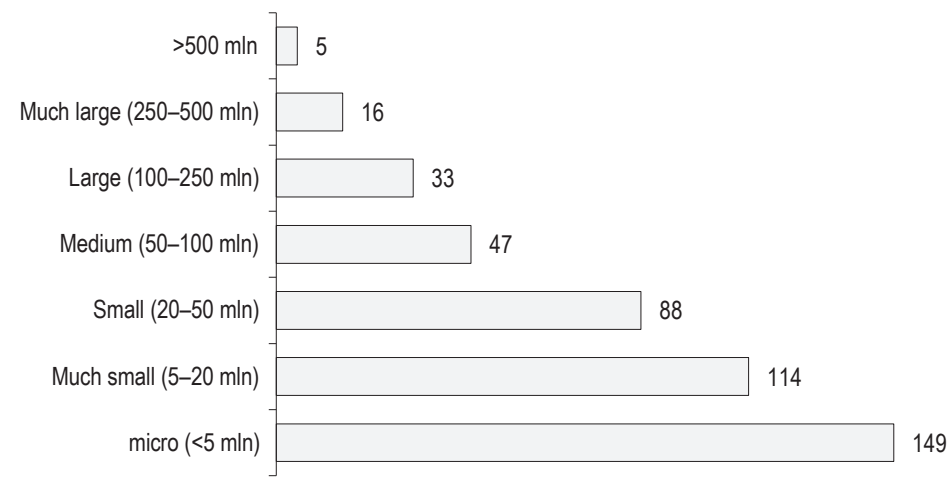

Figure 3. The number of initiated agreements according to the value in 2009-2017

Source: own research and PPP' Institute.

Since 2009, more small-scale projects have been realised. This situation originates from the fact that these projects are prepared by self-governing units, mostly communes, whose budgets are not as large as that of the central government. The results of this are seen in the sectors, where private public partnerships were involved (Figure 4).

$$
\begin{aligned}
& 131
\end{aligned}
$$

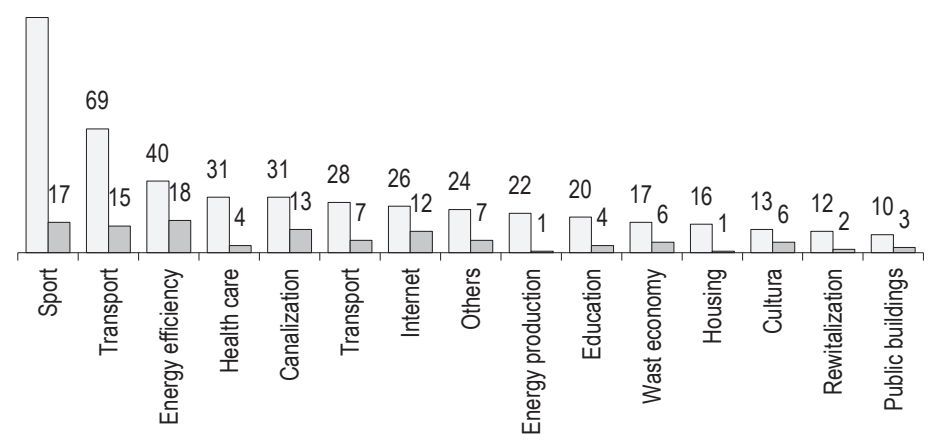

$$
\begin{aligned}
& \square \text { Initiate agreements } \quad \square \text { Realised agreements }
\end{aligned}
$$

Figure 4. Sectors where PPP is initiated and realised in 2009-2017

Source: own research and PPP' Institute.

As we can see, individual projects are being realised in different sectors but the most common areas are sport, transport and energy efficiency, so in these fields, where the needs are the most important, self -governing units are the responsible entities.

The data confirms the previous statements that Polish PPPs take place mainly between the Polish private sector and local self-governing organisations. In Poland, it is local ventures, initiated by the smallest units of local 
government i.e. communes, which prevail. The highest value projects are usually highway projects, which are completed by provincial government authorities (Jachowicz, 2017).

\section{Conclusions}

In the chapters of article, there is presented the analysis of the financial conditions for investment activity of the territorial self-government units in Poland, as well as the main directions of the development of these units. Co-operation with the private sector as a form of investment support for the recommended solutions was also presented. The current situation and future opportunities for financing of the self-government investment was analysed basing on empiric data.

The main conclusions drawn from the paper indicate that the main part of the self-governmental investment in Poland was implemented by communes and district towns (over $70 \%$ of the total). However, having considered participation of investment expenditure in overall spending, the regions featured the highest ratio (of $38.5 \%$ ). In the years 2009-2011, outlays on investment of the territorial self-government units were the highest and in the following years the share of the total spent on such activity was decreasing. The reason for the drop was primarily a high level of indebtedness resulting from realization of investment projects in the previous years (also those co-financed from the EU financial programmes).

The analysis shows also that in Poland, the most common model of PPP are small scale, local projects. Large regional or national investments have only been started. The initiative to take part in the PPP ventures which influences and creates the climate for future developments, occurs in the local government sector, especially at the communal level. Despite the difficulties and lack of the central government support, local government units have begun to see the PPP partnership model as a tool for effectively completing important public sector projects.

\section{References}

Analiza rynku PPP za okres od 2009 do 30 czerwca 2017 (2017). Warszawa: Instytut PPP.

Brzozowska, K., Gorzałczyńska-Koczkodaj, M., Kogut-Jaworska, M., Zioło, M. (2013). Gospodarka finansowa w jednostkach samorządu terytorialnego. Warszawa: CeDeWu.

Burzyńska, D. (2012). Rola inwestycji ekologicznych w zrównoważonym rozwoju gmin w Polsce. Łódź: Wydawnictwo Uniwersytetu Łódzkiego.

EU outlines for PPP (2003). Brussels.

Hajdys, D.M. (2013). Uwarunkowania partnerstwa publiczno-prywatnego w finansowaniu inwestycjijednostek samorządu terytorialnego. Łódź: Uniwersytet Łódzki.

Jachowicz, A. (2015). Partnerstwo publiczno-prywtane narzędziem efektywnej realizacji zadań publicznych. Warszawa: Difin.

Jachowicz, A. (2016). The Effectiveness of Public Private Partnerships in Poland. In: Ł. Sułkowski, H. Sobocka-Szczapa, Ł. Prysiński (eds.), Finansowe I organizacyjne aspekty kooperacji nauki i lokalnej przedsiębiorczości - badania i analizy część II. ŁódźWarszawa: Wydawnictwo SAN.

Jastrzębska, M. (2012). Finanse jednostek samorządu terytorialnego. Wolters Kluwer.

Korbus, B.P., Strawiński, M. (2006). Partnerstwo publiczno-prywtane. Nowa forma realizacji zdań publicznych. Warszawa: Lexis Nexis.

Maśloch, G., Sierak, J. (eds.) (2013). Gospodarka i finanse samorządu terytorialnego. Warszawa: Oficyna Wydawnicza Szkoła Główna Handlowa w Warszawie.

Patrzałek, L. (2010). Finanse samorządu terytorialnego. Wrocław: Wydawnictwo Uniwersytetu Ekonomicznego we Wrocławiu.

Sadowska, B. (2011). The structure of communal income and the possibilities of shaping it. In: M. Stefański, H. Stępień (eds.), Economy and finance of communes in Poland. Selected issues (pp. 77-90). Włocławek: Higher School of Humanities and Economics in Włocławek. 
Sierak, J., Górniak, R. (2011). Ocena efektywności i finansowanie projektów inwestycyjnych jednostek samorządu terytorialnego współfinansowanych funduszami Unii Europejskiej. Warszawa: Oficyna Wydawnicza Szkoły Głównej Handlowej.

Sprawozdanie z działalności regionalnych izb obrachunkowych i wykonania budżetu przez jednostki samorządu terytorialnego dla lat 2009-2016 (2018). Krajowa Rada Regionalnych Izb Obrachunkowych. Retrieved from: http://www.rio.gov.pl.

Swianiewicz, P. (2011). Finanse samorządowe: koncepcje, realizacja, polityki lokalne. Warszawa: Municipium.

Ustawa z 11 lutego 2016 r. o pomocy państwa w wychowywaniu dzieci (Dz.U. 2016, poz. 195).

Ustawa z 27 sierpnia 2009 r. o finansach publicznych (Dz.U. 2017, poz. 2077).

Wskaźniki do oceny sytuacji finansowej jednostki samorządu terytorialnego w latach 2009-2016 (2018). Ministerstwo Finansów. Retrieverd from: http://www.finanse.mf.gov.pl.

Zawora, J. (2014). Możliwości finansowania inwestycji gmin wiejskich w Polsce. Roczniki Naukowe Stowarzyszenia Ekonomistów Rolnictwa i Agrobiznesu, 6 (16).

Zawora, J., Kogut-Jaworska, M., Jachowicz, A. (2017). Działalność inwestycyjna gmin w Polsce. Radom: Instytut Naukowo-Wydawniczy Spatium.

Zioło, M. (2012). Finansowanie inwestycji komunalnych przez banki. Annales Universitatis Mariae Curie-Skłodowska. Sectio H. Oeconomia, 4 (46).

Zioło, M. (2013). Makroekonomiczne zależności pomiędzy inwestycjami publicznymi a wzrostem gospodarczym, deficytem i długiem publicznym. Zarzadzanie i Finanse. Gdańsk: Wydział Zarządzania, Uniwersytet Gdański.

Cite this apticle aS: Jachowicz, A., Kogut-Jaworska, M., Zawora, J. (2018). Investment activity of the territorial self-government in Poland. European Journal of Service Management, 3 (27/1), 99-107. DOI: 10.18276/ejsm.2018.27/1-12. 